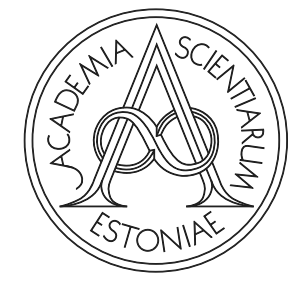

Proceedings of the Estonian Academy of Sciences, $2021,70,4,429-435$

https://doi.org/10.3176/proc.2021.4.09

Available online at www.eap.ee/proceedings

MANUFACTURING

ENGINEERING

\title{
Use case of Autonomous Vehicle shuttle and passenger acceptance analysis
}

\author{
Krister Kalda $^{\mathrm{a}^{*}}$, Raivo Sell b,a and Ralf-Martin Soe ${ }^{\mathrm{a}}$ \\ a Department of Mechanical and Industrial Engineering, Tallinn University of Technology, Estonia \\ ${ }^{\mathrm{b}}$ FinEst Twins Smart City Centre of Excellence, Tallinn University of Technology, Estonia
}

Received 18 June 2021, accepted 15 July 2021, available online 3 November 2021

(C) 2021 Authors. This is an Open Access article distributed under the terms and conditions of the Creative Commons AttributionNonCommercial 4.0 International License (http://creativecommons.org/licenses/by-nc/4.0/).

\begin{abstract}
Autonomous vehicles (AVs) are moving from test areas to the streets, which is one of the key components of smart cities and the future of mobility as a service (MaaS). In 2020, two AV services were operated in Tallinn. This paper focuses on one of these services, and its set-up process. The pilot project took place in Ülemiste City, a tech park with 10000 people working daily in the area, and it connected the offices with the airport and a shopping centre. The autonomous shuttle iseAuto, created first at TalTech, was used for the service (on streets with heavy traffic, including some complex crossings). Our findings associated with the Ülemiste experiment are presented in the context of legal requirements set upon autonomous vehicles to be street legal. Some events that occurred during the operation (including an accident) are addressed and a summary of the feedback from clients is presented. Further studies should focus on the extended concept of smart cities with a roadmap for the nearest future.
\end{abstract}

Key words: autonomous vehicles, smart city, self-driving car, last-mile shuttle.

\section{INTRODUCTION}

Autonomous driving is revolutionizing transportation and is going to change the whole paradigm in the near future. The autonomy is divided into five levels by the Society of Automotive Engineers SAE J3016 [1], where Level 0 refers to no autonomy at all and Level 5 means full autonomy in any conditions. Most of today's advanced and well known self-driving cars, such as Tesla Autopilot, are in Level 2 while low-speed autonomous vehicle (AV) shuttles/robot buses operate up to Level 4. First/last-mile AV shuttles have gained much interest recently by cities to pilot new transport opportunities in a specific area or route to extend the main public transport lines. The pilot experiments allow us to introduce self-driving technology to citizens of the community and test their maturity in real traffic and urban environments. Tallinn University of Technology (TalTech) started to develop a self-driving

\footnotetext{
*Corresponding author, krister.kalda@taltech.ee
}

autonomous last-mile shuttle - iseAuto [2,3] in June 2017 in cooperation with the private company Silberauto. By using open source software and the chassis of existing electric vehicles, it was feasible to achieve a fully functional AV shuttle within only one year of intensive development. The first prototype shuttle called "iseAuto" was ready exactly a year later (in 2018) for the university's 100th anniversary celebrations. The next logical steps to be taken were to get the vehicle into real open traffic, with an ultimate goal to create a whole new autonomous traffic solution with safer and more environmentally sustainable mobility. Based on the prototype vehicle, several more mature vehicles were created by the industrial partner Auve Tech - the successor of Silberauto.

By 2020, iseAuto was developed to the level (according to both Estonian and EU rules) of being street legal. The most significant changes that had to be made to the prototype were related to the windows, more specifically to the material of the glass, which in accident situations has to break as safely as possible considering the 
passengers inside. The changes concerned also some other rules of M1 and M2 class vehicles set to windscreen wipers, air conditioning, lights, reflectors, seats and interior lighting. Two pilot testing sessions were simultaneously launched in open traffic during the last summer months.

The focus of these two pilot projects was on the selfdriving shuttle usage by all sectors of the population and different groups of public transport users, whether for business or pleasure, under two different conditions of traffic density. Both projects were funded by the European Commission, one project was called Sohjoa Baltic [4] and the other FABULOS [5]. In the Sohjoa Baltic project, which was launched in the recreational park area of Kadriorg, a French AV shuttle Navya Evo was used. But in the FABULOS project, which had its Estonian leg of the test area in Ülemiste City (a tech park with offices for thousands of people, also with the Estonian international Tallinn Airport in the area) - the first ever Estonian built first/last-mile autonomous shuttle iseAuto was made street legal and tested by authorities to grant it the right to drive in real open traffic. FABULOS in Estonia (later in the autumn also in Greece, in a city called Lamia) brought together four partners - TalTech, Auve Tech, Fleet Complete and Modern Mobility. In Estonia, there were also the external consortium partners: Ülemiste City, Ministry of Economic Affairs and Communications, Tallinn Transport Department, Estonian Road Administration, Bercman Technologies, and Ericsson Eesti. In the Sohjoa project, a mobility acceptance factor was investigated [6] and specific feedback gathered. In this paper, the feedback is analysed and the findings are presented.

\section{USE CASE IN ÜLEMISTE CITY}

Cities around the world are experimenting with driverless autonomous vehicles, in particular with AV shuttles to be prepared for future mobility. Several studies in the United States [7] and Europe [8] have demonstrated that innovative cities are willing to deploy autonomous shuttles in the near future and citizens have mostly positive attitudes towards AV shuttles on the streets. In order to set up the use case in Ülemiste as required by the project, several modifications and upgrades were necessary to get legal permission for driving on the public roads. So far iseAuto has been tested only in closed areas (e.g., on a dedicated road on the university campus), but the initial idea was also to turn iseAuto into the first street-legal autonomous vehicle in Estonia. This process generally is, and in this case was, closely observed by different traffic authorities - The Estonian Road Administration, the Estonian Police and the Estonian Rescue Board. The legal environment is not yet mature for self-driving vehicles and differs considerably country by country even within Europe. Detailed analysis was also conducted by the Sohjoa Baltic project which included the legal environment of the Baltic Sea Region as well [9].

First, the authorities tested the hardware (a standard procedure for every vehicle) - whether the lights, windows, seats, tires, etc. are in the adequate condition. Then, test drives were conducted in the designated testing spaces, where they followed how the safety person operated the shuttle in case of need and emergencies. For example, it was observed how the control of the bus was transferred from automated driving to manual control. The braking system, the ability to identify objects in different sizes while driving in automated mode was tested, and how the vehicle acted when it had problems with IT systems. Last but not least, also a driving exam was organized in the area where iseAuto was planned to be operated, with the aim of experiencing and observing all different potential situations in traffic, as well as testing how the AV really acts in crossings and in relation to other members (including people) both in static and moving condition. After tests and modifications according to the prescribed rules of the authorities, the shuttles were restructured to meet the standards and were granted the permission to enter the public road traffic as EU M1 category vehicles. In parallel, new intelligent functions such as human-autonomous vehicle interaction methods [10] were experimented on TalTech campus by the Autonomous Vehicles research group.

The route in Ülemiste was chosen due to its different kinds of crossings, turns and the density of both traffic and people with the purpose of connecting the offices of Ülemiste City with a large shopping mall and a hotel in that area, as well as with the international Tallinn Airport. The route and list of bus stops are shown in Fig. 1.

Three AV shuttles were dedicated to the service, with engineers and technicians working daily on the details to advance the buses for the service and thus for future developments. Also, the operator's interface was developed on the accompanying tablet with controls connected to the controls of the shuttle. One of the important functions under testing was teleoperation, see the remote operation workstation in Fig. 2. Teleoperation enables the vehicle to be taken over in case human supervision is needed. This happens usually when unexpected situations occur on the route and shuttles cannot handle them on their own. Teleoperation is also vital to get the autonomous vehicles to Level 5, so that there will not even be a safety operator onboard the vehicle in the future. One of the ultimate goals is to control the traffic from afar, and thus the traffic will become safer to all members when the so-called human errors are eliminated.

The shuttles were not provided any special separate lanes, but were really merged into open traffic. The max- 


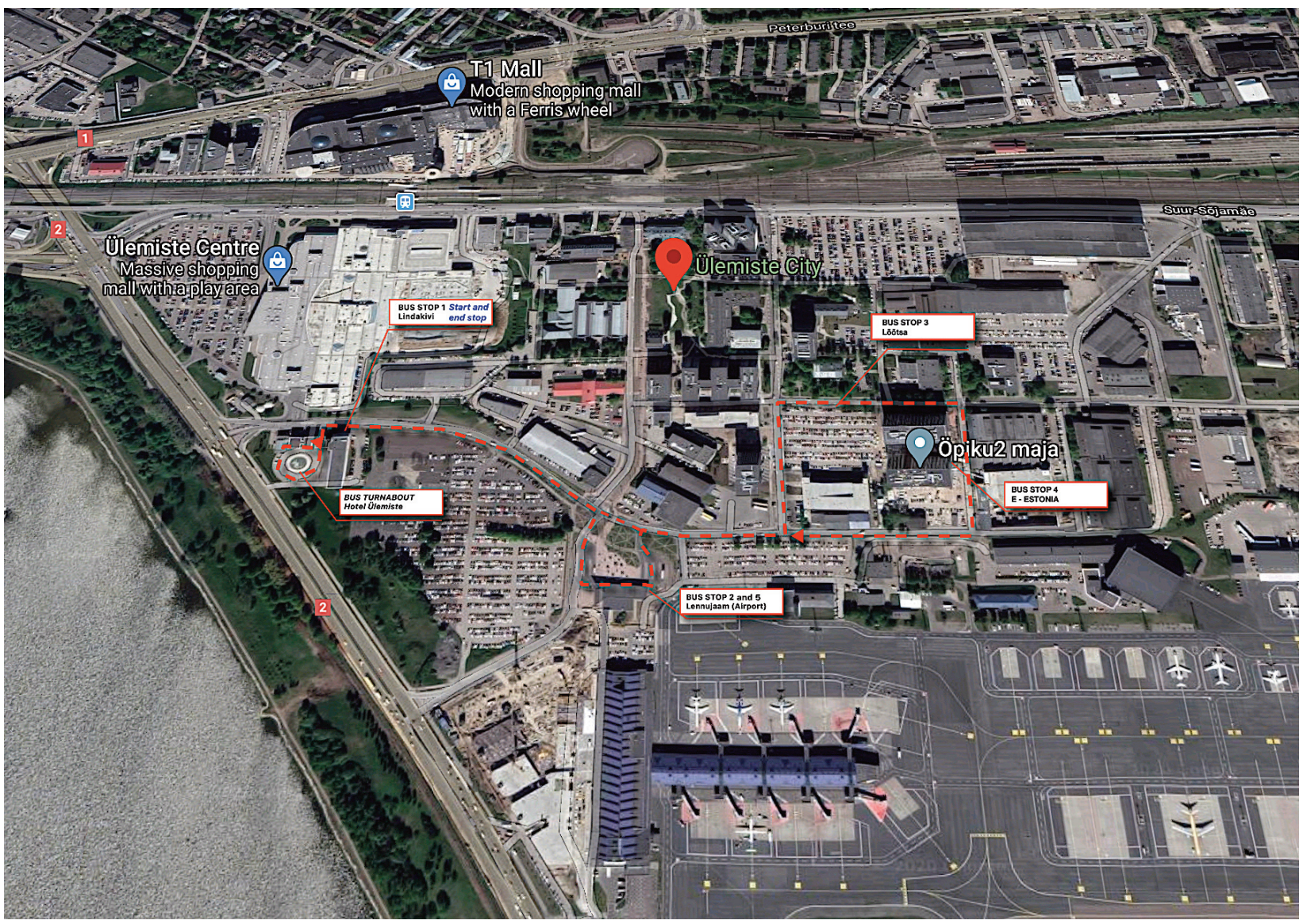

Fig. 1. Test route and stops in Ülemiste City.

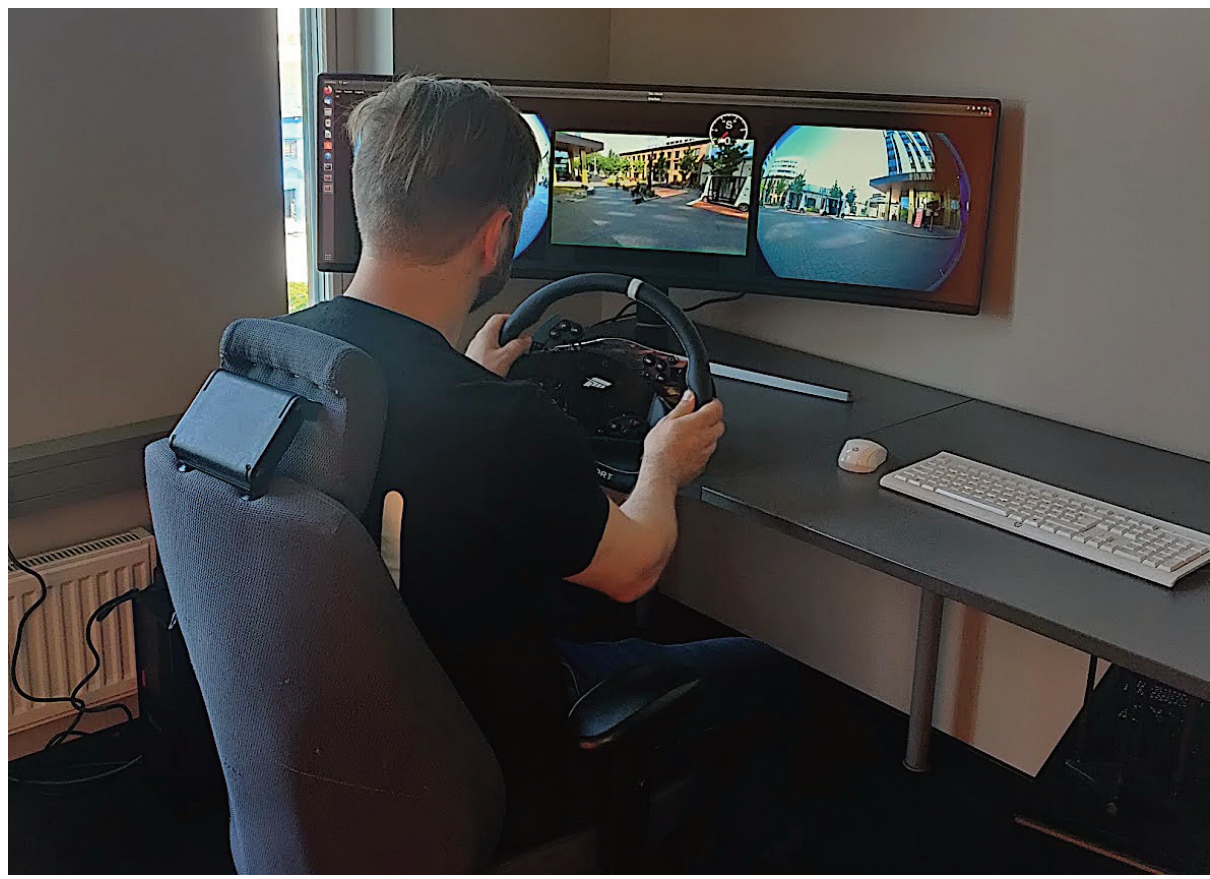

Fig. 2. Teleoperation in Ülemiste remote operation station. 
imum speed allowed on the route was $30 \mathrm{~km} / \mathrm{h}$, but the speed was maintained around $\max 20 \mathrm{~km} / \mathrm{h}$, just for extra safety reasons. The drive included both left and right turns, crossing of the tram and bus lanes prioritized for public transport which serviced the airport. At the same time it was important not to forget the pedestrians, bikes and especially electric scooters of the people working in a tech savvy environment. For passengers, it was free of charge to use the services and the operational schedule was daily between 10:00 and 16:30. All the vehicles used on the route and one backup bus doing the demo ride can be seen in Fig. 3.

Another main focus of the pilot project was to test smart bus stops, with actual real-time info about the arrivals and departures displayed in the stations the whole time, while also recalculating if there had to be longer stops on the way or if the shuttle had to be removed from the rotation. These stops were crucially located: two stops in the middle of the business park, close to the offices, the third at the public transport hub of the airport (where also city trams and buses had their airport stations, linking thus the whole route to the city centre as well) and the forth stop was next to the hotel, being at the same time close to the shopping centre. Since the test pilot project ran only during summer months, the operation in drastic weather conditions that Estonia occasionally has during autumn and especially in winter months could not be tested, but there was heavy rain and winds alternating with mostly nice and sunny weather. There were wrongly parked cars on the shuttles' predetermined driving way, but since the AVs can easily pass obstacles, nothing more serious than a sudden stop happened in these special cases. As all the passengers have to wear a seatbelt and be seated, nobody was frightened (according to our survey on board and on the Internet during the service; this was one of our concerns and questions).

But the pilot project did feature one (and the first) major traffic accident, which taught first and foremost communication skills and that a predetermined action plan had to be adopted between the partners for all occasions - also risk management with a clear communication plan in unexpected situations. The accident was not caused by technical issues or the autonomous shuttle's safety operator. In fact, he could not expect it as the accident was

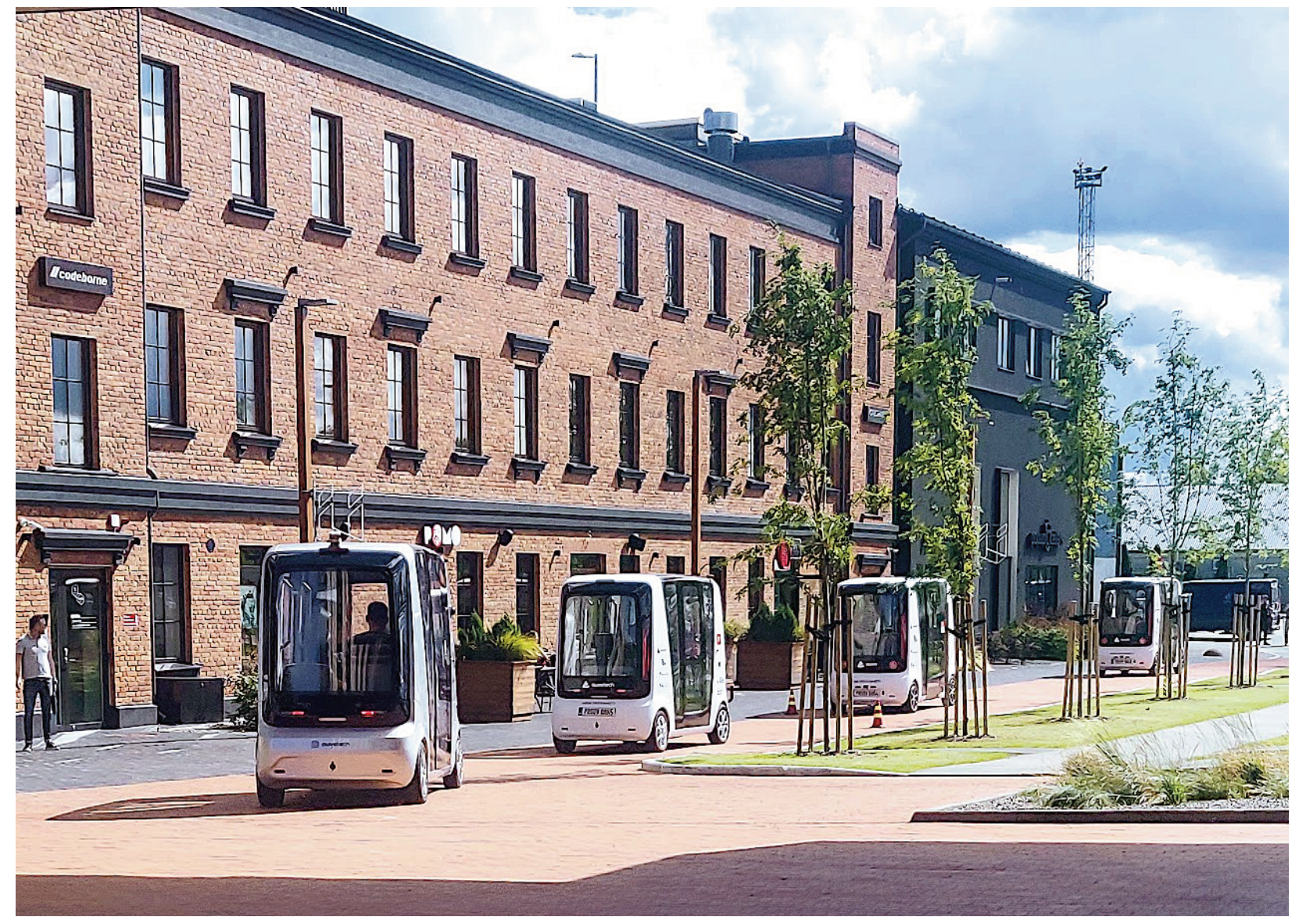

Fig. 3. iseAuto AV shuttle deployment in Ülemiste City. 
caused by a private car that neglected the "give way" traffic sign, drove out on the road in the last second, and due to that the collision happened. The public and the media were fast to put the blame on the AV shuttle, but it was inspected quickly by the police and already in a couple of hours a press release was sent to all the main media channels to correct their assumptions. Nevertheless, it did expose the attitude of the public and the media who first want to judge a new technology which, on the contrary, makes the future traffic safer. In fact, humans make by far more mistakes than IT solutions and radar/lidar/sensor technology guiding the safety of AVs.

However, it has to be pointed out that not so much in a tech park such as Ülemiste City (where innovationminded people are mostly working), but in the other above-mentioned pilot project launched in Kadriorg, in an area with a number of bikers and recreational park visitors, substantially more potential collision situations occurred (although due to the special attention of the safety operators not a single crash happened). Some of the bikers and walkers wanted to test the automated braking system by getting too close to the vehicle, which caused unnecessary dangerous situations both for the passengers inside the vehicle and the pranksters outside. Regardless of it nothing serious happened, and the only reason to postpone the start of the day or sometimes stop the service was related to making technical updates to the shuttles.

We carried out surveys in both pilot projects and used quite many of the similar questions for later comparison. In this research, however, we display the outcome of the major findings obtained directly from the Ülemiste City pilot project, where for the first time the

Table 1. Pedestrian feedback on safety and attitude

\begin{tabular}{|l|l|}
\hline $\begin{array}{l}\text { Average score for overall } \\
\text { experience }\end{array}$ & 6.57 (out of 7.00 maximum) \\
\hline $\begin{array}{l}\text { Average score for traffic } \\
\text { safety }\end{array}$ & 5.95 \\
\hline $\begin{array}{l}\text { Average score for personal } \\
\text { safety }\end{array}$ & 6.27 \\
\hline $\begin{array}{l}\text { Average score for ease of } \\
\text { use }\end{array}$ & 6.45 \\
\hline
\end{tabular}

first Estonian-built fully legal Level 4 autonomous vehicle was used in open traffic.

The aim of the survey was to learn more about what people really think regarding autonomous vehicles, more specifically about first/last-mile AVs, and to reflect their user experience. The survey was carried out during the two months that the pilot project took place in Ülemiste. It will even be used in future surveys as a refence and quideline to some of the questions that need to be asked again and again in the course of time, to identify the change in attitudes and overall knowledge about the potential and opportunities that this kind of new transport offers.

\section{USE CASE SURVEY}

Altogether we had 514 passengers. The operation on the public streets lasted for two months (mostly June and July 2020). The length of the route was $2.4 \mathrm{~km}$ and the total mileage of the shuttles was $2500 \mathrm{~km}$.

When talking to the passengers during their drive, they expressed that once using the $\mathrm{AV}$, they appreciated it more than they thought they would when not really knowing what it meant to drive in one. For the project, it also shows in the unexpectedly high marks on safety. $10 \%$ (51) of all the passengers participated in the survey, some examples of the research results are presented in Tables 1 and 2 and illustrated by charts in Figs 4 and 5.

\section{CONCLUSIONS}

While the project introduced many new challenges that had not been tested before, it also gave many new insights and indicated daily what changes were needed to make

Table 2. Pedestrian feedback on the usage intention

\begin{tabular}{|l|l|}
\hline $\begin{array}{l}\text { I would use an automated shuttle bus } \\
\text { during daytime }\end{array}$ & $94.1 \%$ (out of 51 pax) \\
\hline $\begin{array}{l}\text { I would use an automated shuttle bus } \\
\text { during nighttime }\end{array}$ & $59.9 \%$ \\
\hline $\begin{array}{l}\text { I would never use an automated } \\
\text { shuttle bus }\end{array}$ & $0.04 \%$ \\
\hline
\end{tabular}




\section{WOULD YOU USE IT IN DAILY TRAVEL?}

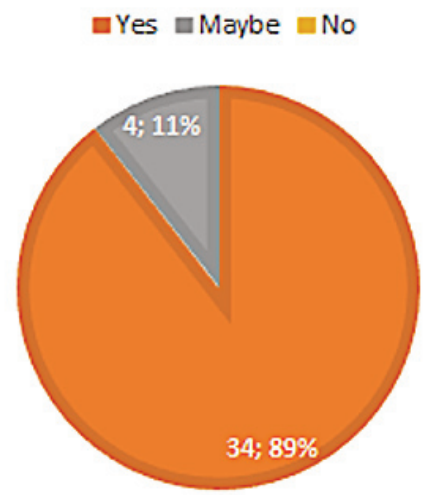

\section{WOULD AN AUTOMATED SHUTTLE BUS BE SUITABLE AS A SCHOOL BUS?}

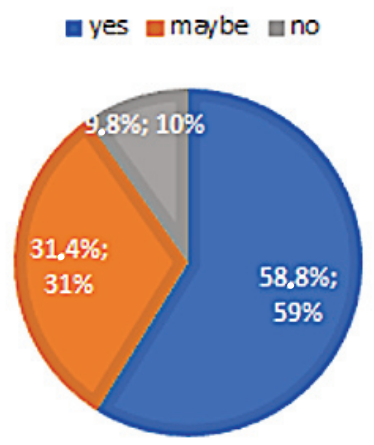

Fig. 4. Two charts on passengers' safety perception.

\section{When would you use an automated} shuttle?

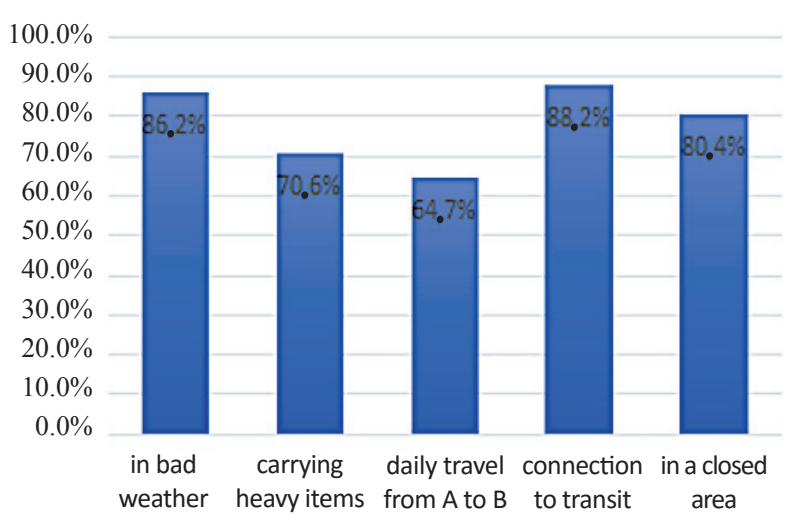

What transport could be replaced with AV shuttles?

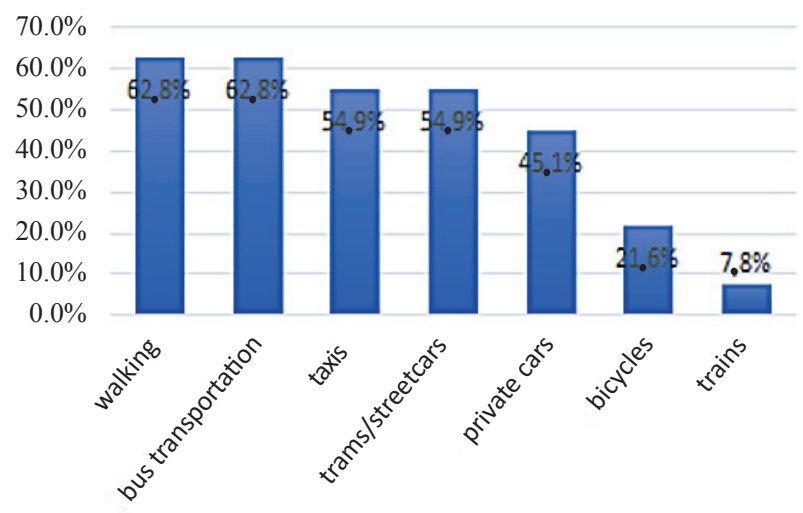

Fig. 5. Survey results on passengers' estimations of AV shuttles.

shuttles safer and more convenient for both the operators and clients. People are interested in trying autonomous vehicles, although quite many seem to be sceptical of AVs' chance to ever fully replace driver-driven vehicles in the traffic.

Now that this use case has come to an end, ise Auto has received a license to drive in real traffic, and the development of these shuttles to become part of MaaS components in public city transport has taken a huge step forward. We have received valuable feedback from daily users that confirm the need and safety expectations of the AV shuttles coming into service. After the successful pilot project in Tallinn, a pilot project under FABULOS consortium was launched on the streets of a city called Lamia (in Greece), where the local authorities also followed the requirements that the Estonian authorities had established for the vehicle and observed the same rules for that leg of the project as well.

The next three major steps to follow from these 2020 projects are: a shuttle service without any operator onboard in 2021 (closer to Level 5 - fully autonomous); creation of transport corridors by servicing rural areas with on-demand first/last-mile autonomous shuttles that will take people closer to the major public transport stops more conveniently (which will at the same time create a more sustainable and healthier environment); and the overall AV integration into the public transport ecosystem in 2022 (with cyber security being also an important issue in all forthcoming developments, due to the fact that $\mathrm{AVs}$ are connected and teleoperated over the Internet). 
The ultimate goal is to encourage more and more people to use public transport instead of contributing to ever intensifying traffic on the streets with their private cars, in addition to not having sufficient parking spaces available in the cities.

\section{ACKNOWLEDGEMENTS}

This research received funding from two grants: the European Union's Horizon 2020 Research and Innovation Programme, under the grant agreement No. 856602, and the European Regional Development Fund, co-funded by the Estonian Ministry of Education and Research, under the grant agreement No. 2014-2020.4.01.20-0289. The publication costs of this article were covered by the Estonian Academy of Sciences and Tallinn University of Technology.

\section{REFERENCES}

1. On-Road Automated Driving (ORAD) committee. Taxonomy and definitions for terms related to driving automation systems for on-road motor vehicles. https://doi.org/10.4271/ j3016_201609
2. Sell, R., Leier, M., Rassõlkin, A. and Ernits, J. Self-driving car ISEAUTO for research and education. In Proceedings of the 2018 19th International Conference on Research and Education in Mechatronics (REM), Delft, Netherlands, June 7-8, 2018. IEEE, 111-116.

3. Rassõlkin, A., Sell, R. and Leier, M. Development case study of the first estonian self-driving car, iseauto. Electr. Control Commun. Eng., 2018, 14(1), 81-88.

4. Mäkinen, S., Kantala, T., Haapamäki, T., Olin, J. and Åman Kyyrö, M. User Experience and Impact on Public Transport - Sohjoa Baltic. The Roadmap to Automated Electric Shuttles in Public Transport. Metropolia University of Applied Sciences, Helsinki, 2020.

5. FABULOS (Future Automated Bus Urban Operation Systems) project. https://fabulos.eu (accessed 2020-01-10).

6. Soe, R.-M. and Müür, J. Mobility acceptance factors of an automated shuttle bus last-mile service. Sustainability, 2020, 12(13), 5469.

7. Norton, B. E. Autonomous shuttles in Santa Fe Springs. California Polytechnic State University, 2020.

8. Hagenzieker, M. P., Boersma, R., Velasco, J. P. N., Öztürker, M., Zubin, I. and Heikoop, D. Automated buses in Europe: an inventory of pilots, 2020.

9. Werdin, S. The roadmap to automated electric shuttles in public transport - the legal framework. Sohjoa Baltic, 2018.

10. Wang, R., Sell, R., Rassolkin, A., Otto, T. and Malayjerdi, E. Intelligent functions development on autonomous electric vehicle platform. J. Mach. Eng., 2020, 20(2), 114-125.

\title{
Eesti esimene pilootprojekt pärisliikluses Eesti esimese tänavalegaalse neljanda taseme isejuhtiva sõidukiga
}

\author{
Krister Kalda, Raivo Sell ja Ralf-Martin Soe
}

Isejuhtivad sõidukid sisenevad testialadelt tänavatele, mis on üheks võtmekomponendiks ka tarkades linnades ja tuleviku mobiilsusteenuste (MaaS) osa. 2020. aastal pakuti Tallinnas kaht isejuhtiva sõiduki teenust. Artiklis on keskendutud ühele neist, sisaldades infot, kuidas see üles ehitati. Pilootprojekt toimus Ülemiste linnaku tehnopargis, kus igapäevaselt töötab 10000 inimest. Teenus ühendas kontorid lennujaama ja ostukeskusega. Selleks teenuseks kasutati isejuhtivat bussi iseAuto, mille esimene prototüüp loodi Tallinna Tehnikaülikoolis (tänavatel, kus toimus tavaliiklus ja kus olid ka mõned keerulised ristmikud). On esitatud ka Ülemiste eksperimendi testide tulemused, mis on seotud seaduse nõuetega isejuhtivatele sõidukitele, samuti juhtumid, mis toimusid eksperimendi käigus, sh liiklusõnnetus. On ka kokkuvõte küsitlusest, mille korraldasime sõitjate seas, ja edasised uurimused, mis peaksid keskenduma tarkade linnade kontseptsiooni edasiarendamiseks lähitulevikus. 